\title{
The creation of pollution mapping and measurement of ambient concentration of sulfur dioxide and nitrogen dioxide with passive sampler
}

\author{
Andaç Akdemir
}

\begin{abstract}
Background: Measurements of nitrogen and sulfur dioxide using passive sampler over 12 months in Samsun, Turkey, are compared with $\mathrm{SO}_{2}$ and $\mathrm{NO}_{2}$ concentrations obtained from a co-located chemiluminescence analyzer. The concentrations of Sulfur and nitrogen dioxide in the ambient air during the period from November 2009 to September 2010 are analyzed.

Results: The highest value for annual $\mathrm{NO}_{2}$ and $\mathrm{SO}_{2}$ averages of passive sampler was $29.65 \mu \mathrm{g} / \mathrm{m}^{3}$ and $21.01 \mu \mathrm{g} / \mathrm{m}^{3}$ for exposures of 2-weeks at an industrial site. The maximum monthly concentration for $\mathrm{SO}_{2}$ was observed at the $10^{\text {th }}$ measurement station with $44.19 \mu \mathrm{g} / \mathrm{m}^{3}$ for August. The maximum monthly concentration for $\mathrm{NO}_{2}$ was observed on the $3^{\text {rd }}$ measurement station with $42.83 \mu \mathrm{g} / \mathrm{m}^{3}$ for November. A negative correlation between nitrogen dioxide concentrations and temperature $\left(R^{2}=-0.5489\right)$ was estimated. A positive correlation between nitrogen dioxide measurement with passive sampler and continuous measurement $\left(R^{2}=0.6571\right)$ was estimated.
\end{abstract}

Keywords: Passive sampler, Sulfur dioxide, Nitrogen dioxide

\section{Background}

Industrial establishments operating in the Samsun Industrial Zone for years, activities of the mobile power plants opened but then closed down and natural gas combined cycle plant scheduled to be reactivated require detailed studies of the region in terms of air pollution. The readings of the measurements made with uninterrupted system measurement devices at one single location revealed that the limit values of the European Union were exceeded seasonally in terms of nitrogen dioxide. However sulfur dioxide values did not exceed national and international legislations in any period (See Table 1) [1].

In the first instance the passive sampler was developed in America as an on-person air sampler by Palmes et al. (1976), it ensures that gas or vapor on the atmosphere is carried by molecular diffusion with a physical process and kept in a membrane. Here, the effective power is

Correspondence: aakdemir@omu.edu.t

Engineering Faculty, Department of Environmental Engineering,

Ondokuz Mayıs University, 55200 Samsun, Turkey concentration change between the absorption surface and the air surrounding it and the amount of diffusion occurred is given on $1^{\text {st }}$ Fick rule on equation (1) [6].

$$
\mathrm{F}=-\mathrm{D} \cdot \mathrm{dC} / \mathrm{dL}
$$

Where; $\mathrm{F}$ is the molar flux $\left(\mu \mathrm{g} \cdot \mathrm{cm}^{-2} \cdot \mathrm{min}^{-1}\right), \mathrm{D}$ is the diffusion coefficient $\left(\mathrm{cm}^{2} / \mathrm{min}\right), \mathrm{C}$ is the concentration $\left(\mu \mathrm{g} . \mathrm{cm}^{-3}\right)$, and $\mathrm{L}$ is the diffusion path $(\mathrm{cm})$. The contaminant concentration kept in the passive sampler depends of the period of atmosphere exposure, quantity of total gas transfer collected in the passive sampler tube, geometric structure of the tube and diffusion coefficient, ambient temperature, ambient humidity, sorbent strength and face velocity. Passive sampler is a preferred method since it does not require power supply, has cost-efficient investment, light, simple analysis procedure as well as not requiring calibration, and suitable for simultaneous multipoint measurement of ambient air pollution. Passive samplers are extremely useful to assess long-term concentration trends (e.g., yearly) and are small, light, re-usable, and 
Table 1 National and international ambient air quality standards for $\mathrm{SO}_{2}$ and $\mathrm{NO}_{2}$ (as ppb)

\begin{tabular}{llllll}
\hline Pollutants & Period & RG [2] & EU [3] & WHO [4] & NAAQS [5] \\
\hline Sulfur Dioxide & 1-hour & 57.25 & 350 & - & 75 \\
& 24-hour & 47.71 & 125 & 7.63 & - \\
& 3-hour & - & - & - & 500 \\
& Annual & 7.63 & - & - & - \\
Nitrogen Dioxide & 1-hour & 53.14 & 200 & 10.63 & 100 \\
& 24-hour & - & - & - & - \\
& Annual & 10.63 & 74,40 & 21.26 & 53 \\
\hline
\end{tabular}

soundless [7-11]. Nitrogen dioxide has an irritant effect on the respiratory organs, and long exposures can increasingly lead to airway disorders, such as chronic bronchitis [12]. The major health impact of sulfur dioxide include effects on breathing, respiratory illness, weakness of lung defenses, increase in the effects of existing respiratory and cardiovascular disease, and death [13]. Explanations of effects of pressure, temperature, and wind speed on the samplers for $\mathrm{NO}_{2}$ and $\mathrm{SO}_{2}$ have been reported [12,14]. Diffusive sampling can be used if the average, instead of the real-time, pollutant concentration is adequate for the purpose of monitoring [15].

\section{Methods}

The measurements took place at an industrial zone located in Samsun Tekkekoy district, Selyeri locality. This district is located on the north-east coast of Turkey. The area is enclosed in the north by the Black sea. The area is also crossed by one of the main Samsun and Turkey highways, the D010 (Figure 1, yellow line). The Industrial zone is nearly $15 \mathrm{~km}$ away from the city center.
The Industrial Zone digital map of Samsun Tekkekoy District, scale 1:50000, is used at the GIS-software ArcGIS (version 9.2, ESRI, CA, USA). The measurement results were introduced in the ESRI Geographic Information System software ArcGIS and the extension geostatistical Analyst was used to obtain distribution maps. The geostatistical Analyst, an extension to ArcGIS, a product of the Environmental Systems Research Institute (ESRI), California, USA, can be applied to analyze the data from air quality monitoring networks and to generate maps of spatial distribution of the monitored air pollutants. Several spatial interpolation methods available were tested. The selected method was the geostatistical interpolation method-linear interpolation for commonly used.

For the pilot study, there were 10 samplers available for field sampling and the sampling area was approximately $20 \mathrm{~km}^{2}$; therefore; samplers were distributed through background locations only using a systematic grid of $1 \times 1 \mathrm{Km}$, as can be seen in Figure 1 . The distances between sampling points are approximately 1 1.5 kilometers. The samplers of site were identified and tracked using a Global Positioning System (Magellan Mobile Mapper TM6). The data on measurement locations are given on Table 2 .

The passive samplers used for the measurements are from English Gradko Company and the technical specifications are explained in detail on Table 3. The analysis of nitrogen dioxide and sulfur dioxide passive samplers were conducted at Gradko's laboratory in England. The analysis is carried out according with Gradko International Ltd Internal Laboratory Quality Procedure. All air analyses have been all conducted by UKAS Accredited Methods, working to ISO 17025. The calibration of sampling tubes was made with Gradko Environmental Laboratory accredited by United Kingdom Accreditation

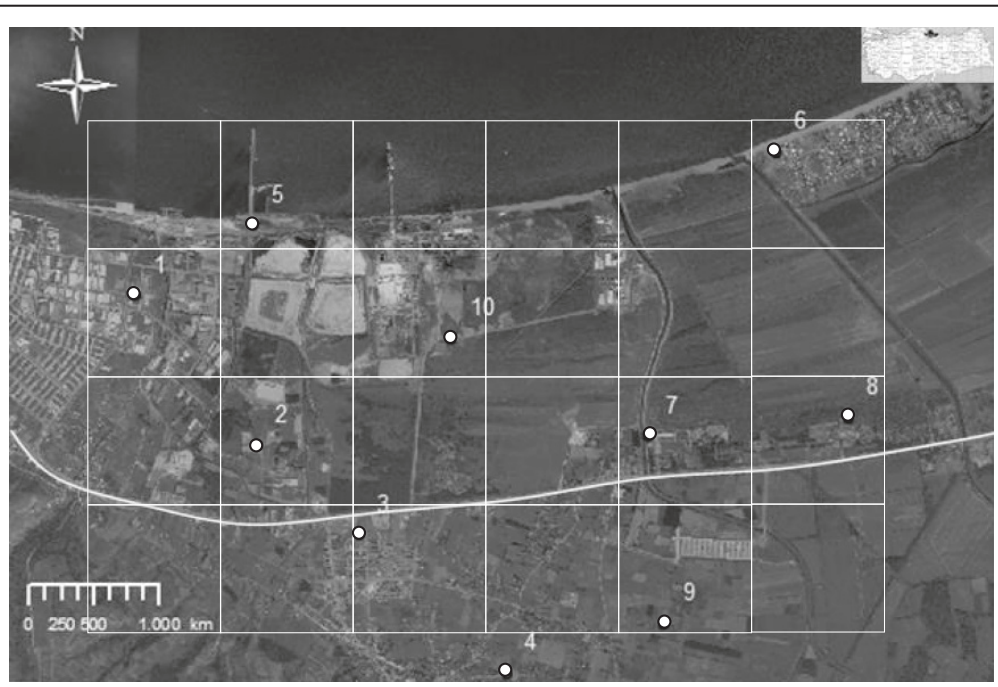

Figure 1 Sampling points in the study area (Google Earth, 2009). 
Table 2 Measurement points and coordinates

\begin{tabular}{lll}
\hline \multirow{2}{*}{ Station no } & \multicolumn{2}{l}{ Coordinates } \\
\cline { 2 - 3 } $\mathbf{N}$ & $\mathbf{E}$ \\
\hline 1 & $41^{\circ} 14^{\prime} 22.0^{\prime \prime}$ & $36^{\circ} 26^{\prime} 2.44^{\prime \prime}$ \\
2 & $41^{\circ} 13^{\prime} 46^{\prime \prime}$ & $36^{\circ} 26^{\prime} 43.7^{\prime \prime}$ \\
3 & $41^{\circ} 13^{\prime} 24.5^{\prime \prime}$ & $36^{\circ} 27^{\prime} 18.2^{\prime \prime}$ \\
4 & $41^{\circ} 12^{\prime} 51.4^{\prime \prime}$ & $36^{\circ} 28^{\prime} 7.7^{\prime \prime}$ \\
5 & $41^{\circ} 14^{\prime} 40.49^{\prime \prime}$ & $36^{\circ} 26^{\prime} 40.52^{\prime \prime}$ \\
6 & $41^{\circ} 15^{\prime} 2.2^{\prime \prime}$ & $36^{\circ} 29^{\prime} 31.1^{\prime \prime}$ \\
7 & $41^{\circ} 13^{\prime} 50.9^{\prime \prime}$ & $36^{\circ} 28^{\prime} 51.9^{\prime \prime}$ \\
8 & $41^{\circ} 13^{\prime} 57^{\prime \prime}$ & $36^{\circ} 29^{\prime} 57.1^{\prime \prime}$ \\
9 & $41^{\circ} 13^{\prime} 4.8^{\prime \prime}$ & $36^{\circ} 28^{\prime} 58.9^{\prime \prime}$ \\
10 & $41^{\circ} 14^{\prime} 13.8^{\prime \prime}$ & $36^{\circ} 27^{\prime} 46.3^{\prime \prime}$ \\
\hline
\end{tabular}

Service (UKAS). The concentrations of Nitrite ions and hence NO2 chemically adsorbed (the grid made of stainless steel impregnated with $20 \%$ triethanolamine) are quantitatively determined by UV/Visible Spectrophotometry (Camspec M550 Spectrophotometer) with reference to a calibration curve derived from the analysis of standard nitrite solutions (UKAS Accredited Methods) which is measured colorimetrical. Likewise, for the sulfur dioxide analysis, the grid made of stainless steel impregnated with potassium hydroxide was extracted and then measured with Dionex IC 3000 ion chromatography. Determined by an overall m.o.u of $14.081 \%+/$ - and a limit of detection of $0.026 \mu \mathrm{g} \mathrm{S}$ for sulfur dioxide. Determined by an overall m.o.u of $10.907 \%+/-$ and a limit of detection of $0.021 \mu \mathrm{g} \mathrm{NO}_{2}$ for nitrogen dioxide.

In order to compare passive samplers with the results of uninterrupted system measurement method operated with chemical optical spectroscopic methods, the data of

Table 3 Properties of passive samplers

\begin{tabular}{|c|c|c|}
\hline Properties & $\begin{array}{l}\text { Nitrogen Dioxide, } \\
\mathrm{NO}_{2}\end{array}$ & $\begin{array}{l}\text { Sulfur Dioxide, } \\
\mathrm{SO}_{2}\end{array}$ \\
\hline Model Number & DIF 100 RTU & DIF 600 RTU \\
\hline Absorbent & $\begin{array}{l}\text { \% } 20 \text { Triethanolamine/ } \\
\text { Deionized Water }\end{array}$ & $\begin{array}{l}\text { Potassium } \\
\text { Hydroxide }\end{array}$ \\
\hline Method of Analysis & $\begin{array}{l}\text { UVNIS } \\
\text { Spectrophotometric }\end{array}$ & $\begin{array}{l}\text { Ion } \\
\text { Chromatography }\end{array}$ \\
\hline \multirow[t]{2}{*}{ Tube Size } & $71 \mathrm{~mm}$ height, & $71 \mathrm{~mm}$ height, \\
\hline & $\begin{array}{l}11 \mathrm{~mm} \text { internal } \\
\text { diameter }\end{array}$ & $\begin{array}{l}11 \mathrm{~mm} \text { internal } \\
\text { diameter }\end{array}$ \\
\hline Duration of Exposure & 14 day & 14 day \\
\hline Amount of Air Intake & $72 \mathrm{~cm}^{3}$. hour ${ }^{-1}$ & $0.95 \mathrm{~cm}^{3}$. hour $^{-1}$ \\
\hline $\begin{array}{l}\text { Average Measurement } \\
\text { Accuracy }\end{array}$ & $+/-\% 3.69$ & $+/-\% 12.38$ \\
\hline Lower Detecting Limit & $0.34 \mathrm{ppb}$ & $0.5 \mathrm{ppb}$ \\
\hline Reference & TS EN 13528/1-3 & TS EN 13528/1-3 \\
\hline
\end{tabular}

the measurement station owned by the Ministry of Environment and Forestry was used (Station No.3). The Station No.3 where the reference method chemiluminescence and UV Fluorescence method for automatic measurement of $\mathrm{NO}_{2}$ and $\mathrm{SO}_{2}$ concentrations and are in use. An automatic ambient $\mathrm{SO}_{2}$ analyzer (AF22M, Environnement S.A, France) and a ambient $\mathrm{NO}_{2}$ analyzer (AC32M, Environnement S.A, France) were used to measure the average concentrations of sulfur dioxide and nitrogen dioxide. The fixed measurement station data was obtained from Air Quality Monitoring Network database. The data were compiled as 14-day average data and then compared with the passive sampler readings.

The measurements started on 18.10.2009 and were completed on 19.09.2010. The measurements were made at total 10 measurement stations. Measurements were performed twice each month to account for the seasonally changing climatic conditions. The passive samplers were located far from walls and $2.0 \mathrm{~m}$ above the ground. While selecting the locations of passive samplers used for the measurements, several particulars were taken into consideration such as; exactly determining the industrial contamination in the region, taking into consideration the impact areas by bearing in mind the dominant wind direction, taking into consideration the impacts of significant point contaminants, preventing the impact of pollution caused by vehicles, minimizing the intervention on parks and of wind, comparing the results with uninterrupted measurement system and ensuring ease and safety of passive sampler installation.

\section{Results and discussion}

The measurement readings obtained for nitrogen dioxide and sulfur dioxide from all measurement stations are given separately on Figures 2 and 3, and seasonal variation of sulfur dioxide and nitrogen dioxide for all stations on Figures 4 and 5. The highest pollutant concentrations were in the 1., 2., and 10 number of stations. The highest average concentrations were in winter for nitrogen dioxide and sulphur dioxide (Figures 4 and 5).

When a digital map of the readings regarding monthly averages of sulfur dioxide measurements between October 2009 and October 2010 was formed by using ArcGIS software, it was observed that the values obtained in August 2009 were the highest and reached up to $154.49 \mu \mathrm{g} / \mathrm{m}^{3}$ (Figure 6). As for the sulfur dioxide; the overall result observation the digital maps prepared by using ArcGis software was that the level of pollution at measurement locations number $1,2,3,4,5$ and 10 , in other words on the south-west and north-west of the region, is higher.

According to the measurement readings calculated for nitrogen dioxide, the highest $\mathrm{NO}_{2}$ values reached up to $43.27 \mu \mathrm{g} / \mathrm{m}$ in November 2009 (Figure 7). 

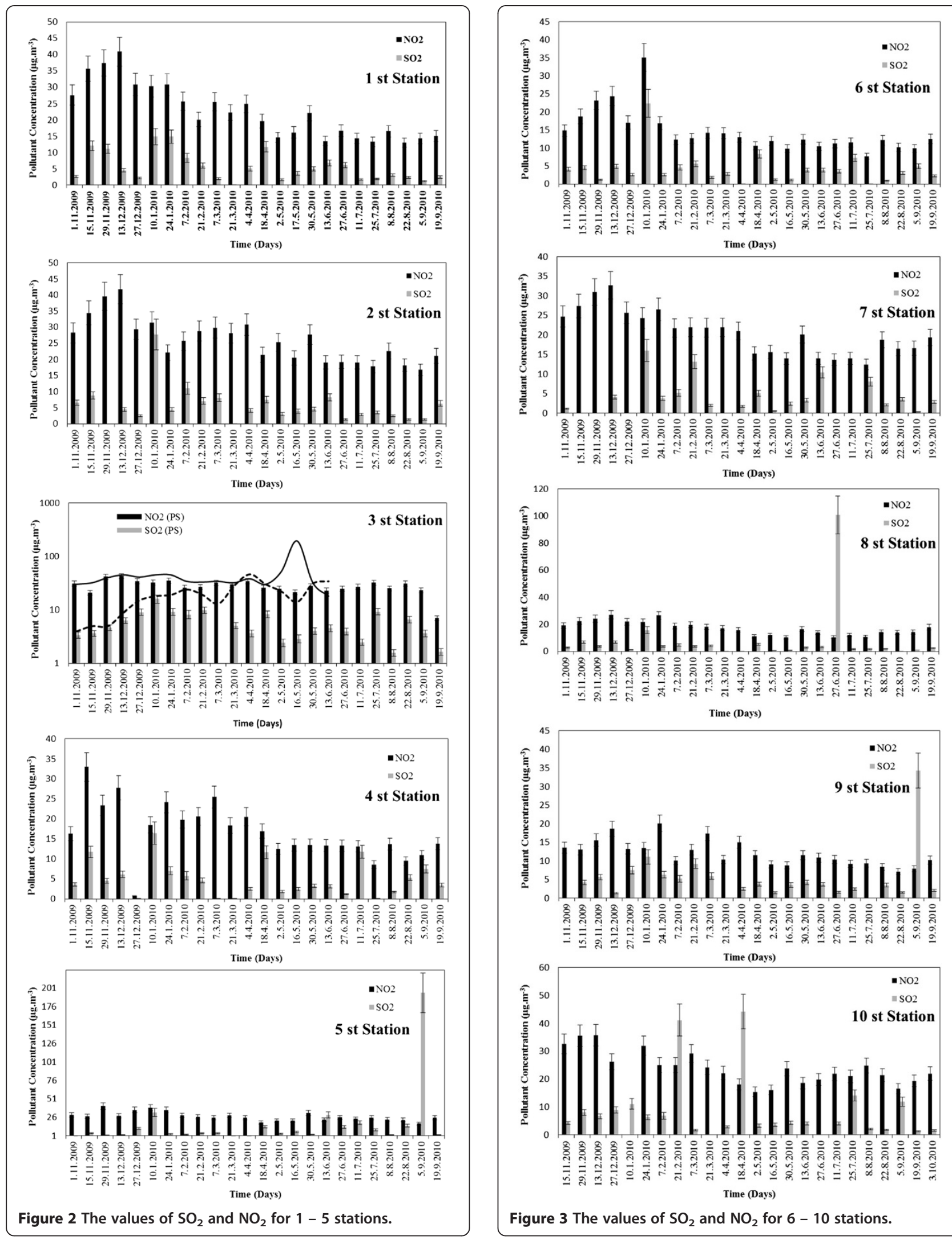

Figure 3 The values of $\mathrm{SO}_{2}$ and $\mathrm{NO}_{2}$ for $6-10$ stations. 

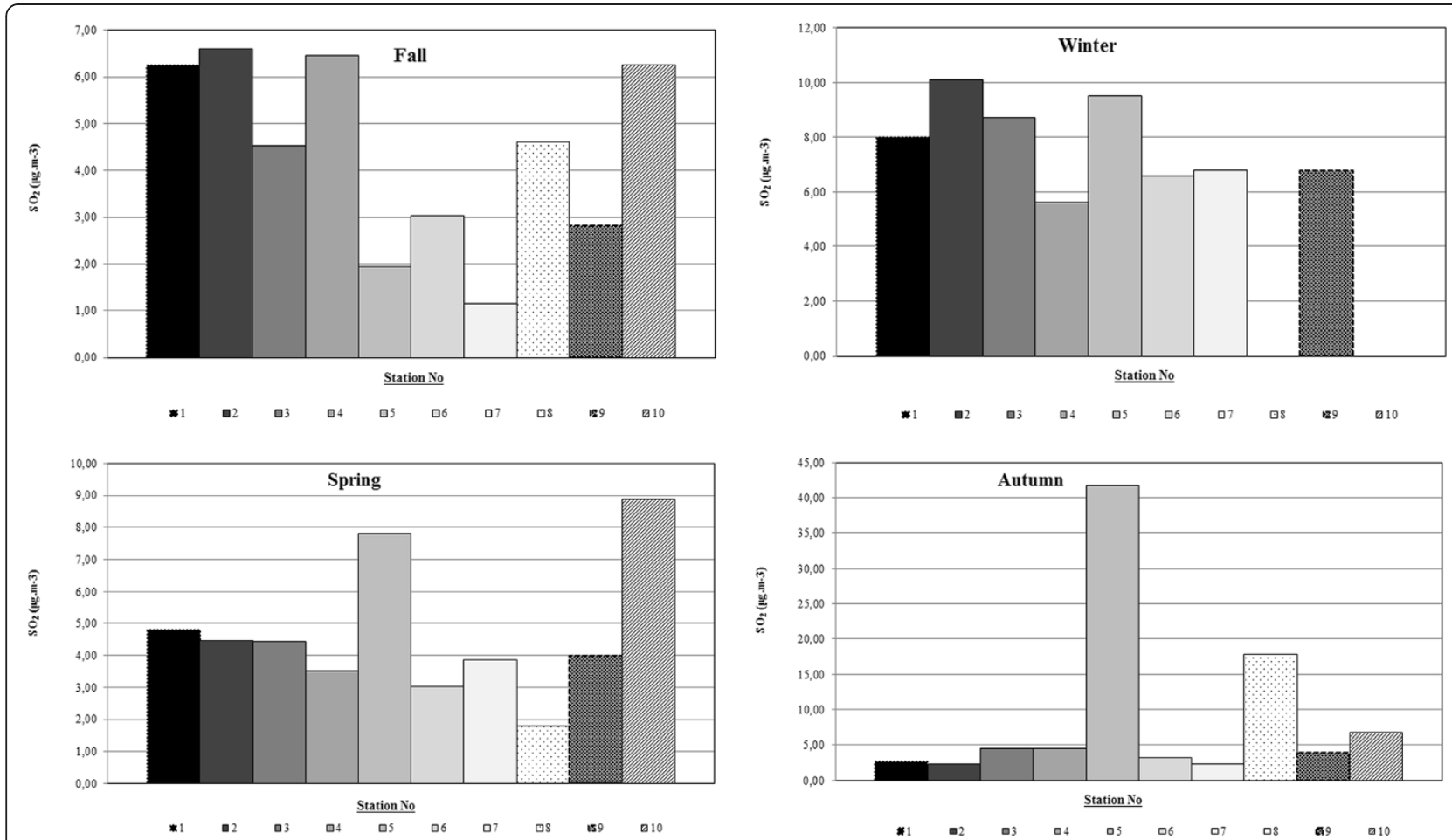

Figure 4 Average values of $\mathrm{SO}_{2}$ concentrations for seasonal variation during 2009-2010.
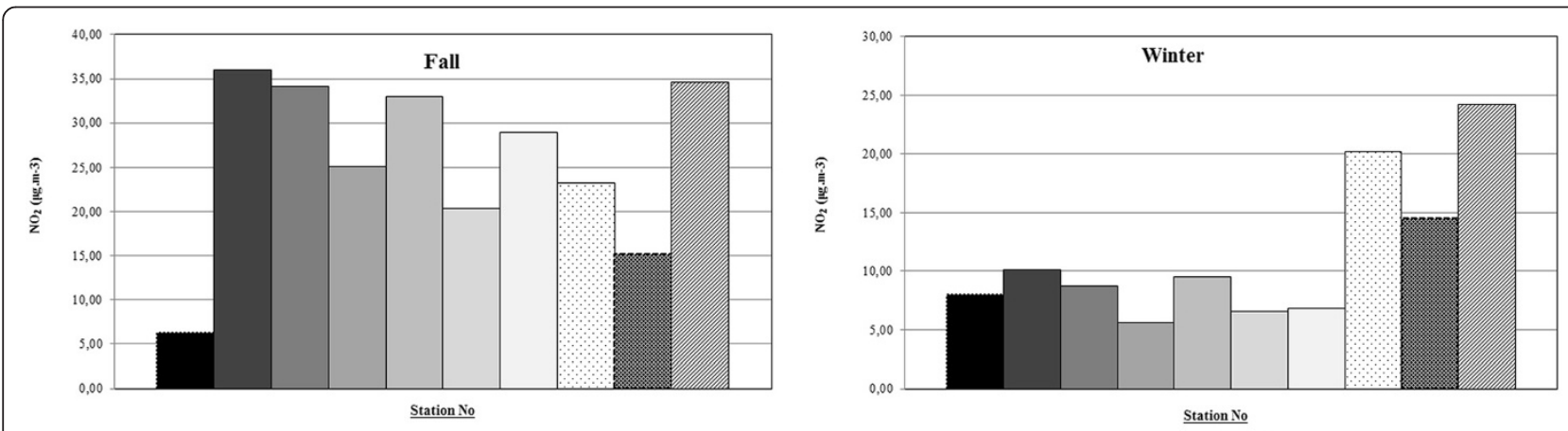

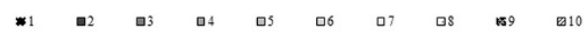
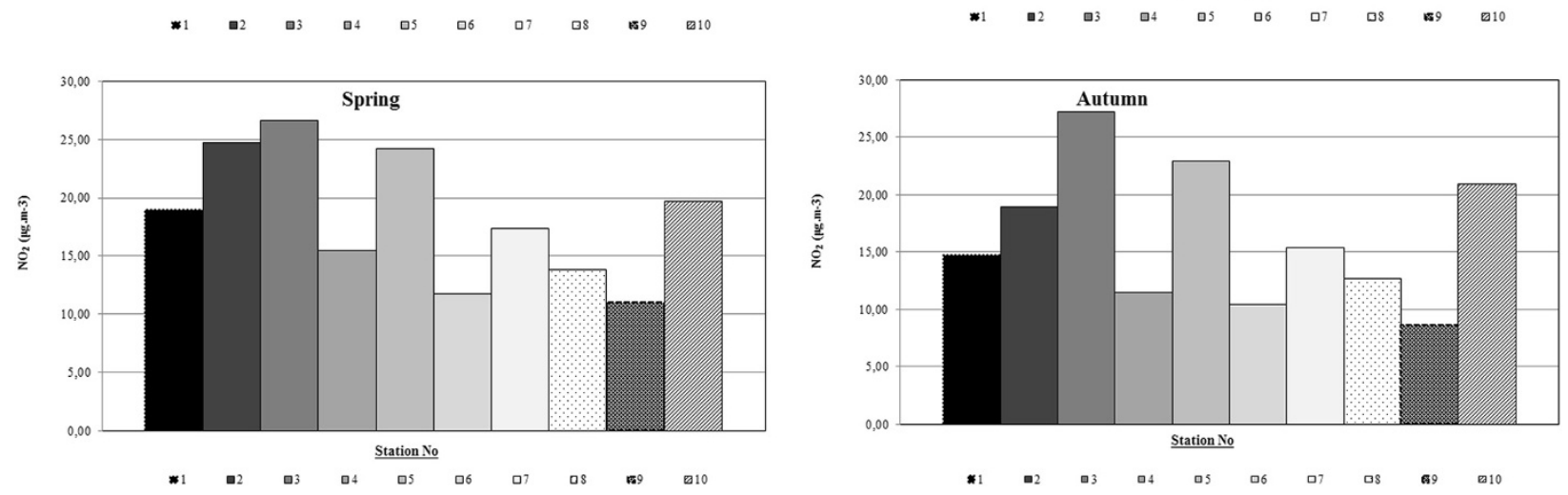

Figure 5 Average values of $\mathrm{NO}_{2}$ concentrations for seasonal variation during 2009-2010. 


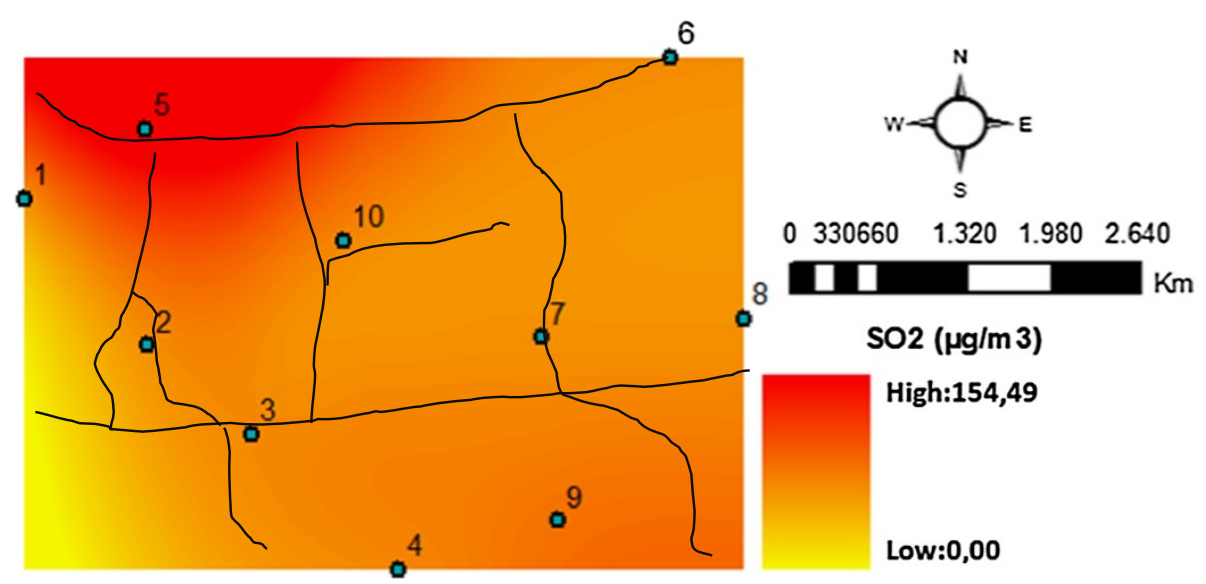

Figure 6 Results of measurement of averaga sulfur dioxide for August 2010 (as the highest mount).

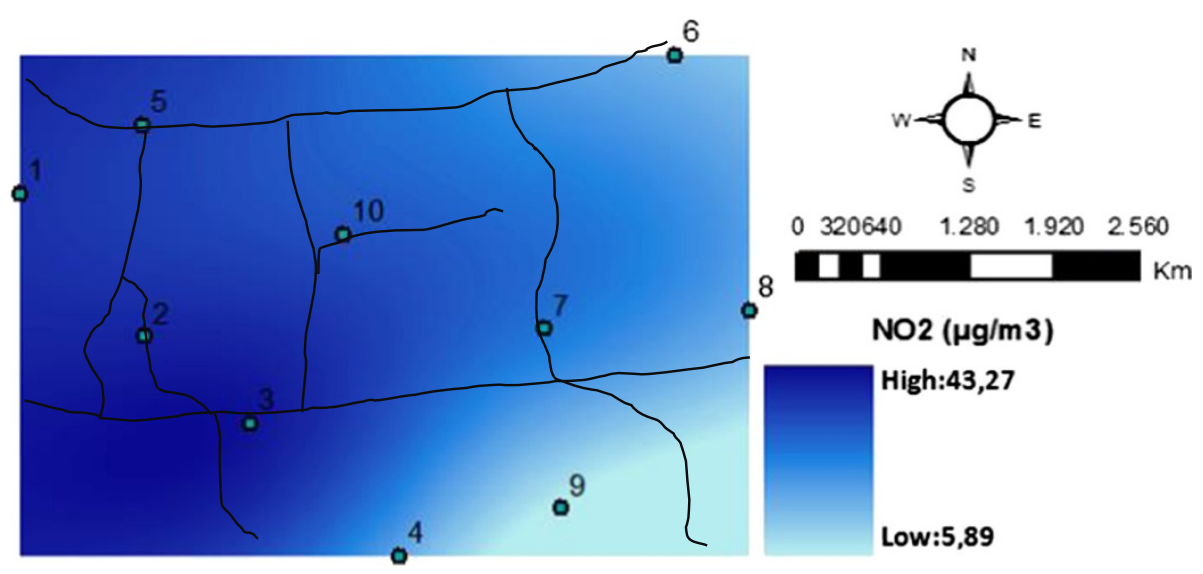

Figure 7 Results of measurement of average nitrogen dioxide for November 2009 (as the highest mount).
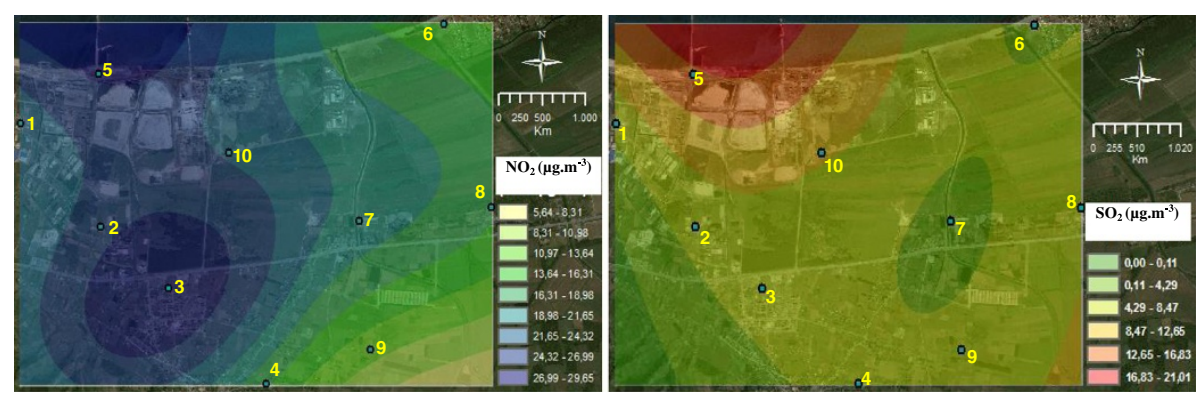

Figure 8 Dispersion of annual average $\mathrm{NO}_{2}$ and $\mathrm{SO}_{2}$ pollutants in Samsun in 2009-2010. 

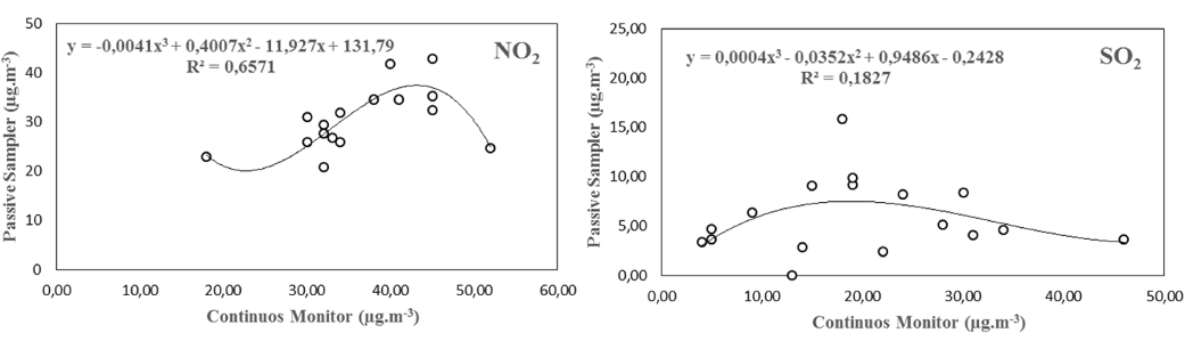

Figure 9 Correlation of passive sampler with continous monitor for $\mathrm{SO}_{2}$ ve $\mathrm{NO}_{2}$.

The highest value for annual $\mathrm{NO}_{2}$ averages was $29.65 \mu \mathrm{g} / \mathrm{m}^{3}$ and $21.01 \mu \mathrm{g} / \mathrm{m}^{3}$ for $\mathrm{SO}_{2}$ (Figure 8).

In order to compare the results obtained with passive sampler method with the measurements made with uninterrupted measurement devices, passive samplers were located at the fixed measurement station of Ministry of Forestry and Water Works, namely Sampling Station Number 3. The measurement readings were obtained from Air Quality Monitoring Network web page as the reference method of chemiluminescence. The arithmetical averages of the 14-day exposure period of the passive samplers were calculated by taking into consideration the daily arithmetical averages of the values. The results of sulfur dioxide and nitrogen dioxide according to two measurement methods so compared are given on Figure 8. Statistically, regression analysis carried out to show the degree of correlation between the continuous monitor and the diffusion tubes gave different regression coefficients. Correlation analysis between passive samplers and the continuous monitor (Figure 9) gave a correlation coefficient $\left(\mathrm{R}^{2}\right)$ of value. According to the uninterrupted system and passive sampler methods used at measurement station number 3, there is a low-level relationship in terms of sulfur dioxide measurement methods $\left(R^{2}=0.1827\right)$ but the relation in terms of nitrogen dioxide measurements is confirmed to be $R^{2}=0.6571$ (Figure 9).

Box-plots of yearly concentrations of $\mathrm{SO}_{2}$ and $\mathrm{NO}_{2}$ measured at the sampling points are given in Figure 10.

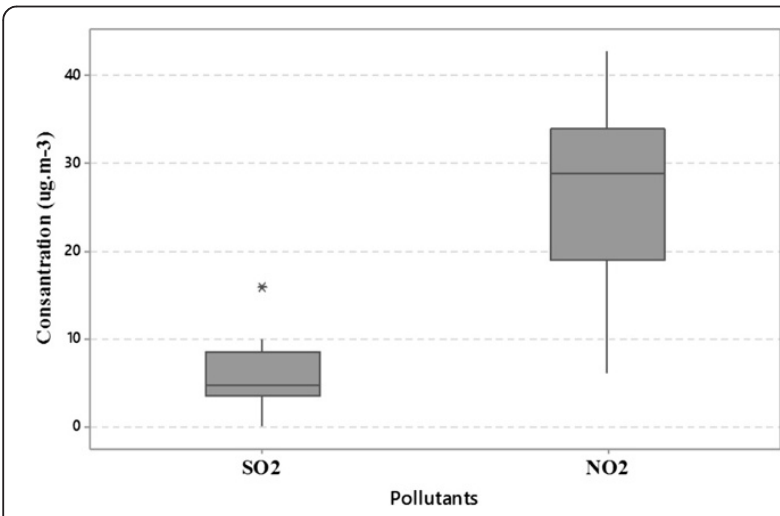

Figure 10 Box-plot of the biweekly average concentrations of measured pollutants.
Each vertical box covers $50 \%$ of the measured values between the lower and highest quartiles. The outliers are plotted separately as small squares and squares. The horizontal line inside the box and the cross represent the median and mean values. $\mathrm{NO}_{2}$ can be seen in Figure 10 to be associated with significantly higher pollution concentrations than $\mathrm{SO}_{2}$.

The measurement readings were interpreted according to the data obtained from Çarşamba Airport Meteorology Station which is the closest one to the region. The coordinates of Çarşamba Airport Meteorology Station are $41^{\circ}$ $15^{\prime} 23.92^{\prime \prime} \mathrm{N}$ and $36^{\circ} 33^{\prime} 23.74 \mathrm{l} \mathrm{W}$, and the distance to the closest measurement locations, namely 6 and 8 , is approximately 5.5 kilometers. The measurement data obtained by the station on the measurement dates are given on Table 4 and the wind rose is given on Figure 11. The wind rose show that the dominant directions of surface wind in Carşamba during period of measurement is $\mathrm{S}$. At a typical meteorological condition of average wind speed 2.8-3.2 m/s.

The correlation between $\mathrm{NO}_{2}$ and $\mathrm{SO}_{2}$ concentrations and meteorological parameters like air temperature, wind speed, and relative humidity was also calculated for the

Table 4 Samsun Çarşamba airPort meteorology station inputs (October, 2009 - September 2010)

\begin{tabular}{lllll}
\hline \multirow{5}{*}{ Date } & \multicolumn{4}{l}{ Monthly average inputs } \\
\cline { 2 - 5 } & $\begin{array}{l}\text { Wind } \\
\text { direction } \\
(\mathbf{(})\end{array}$ & $\begin{array}{l}\text { Wind } \\
\text { speed } \\
(\mathbf{m} / \mathbf{s})\end{array}$ & $\begin{array}{l}\text { Temperature } \\
\left({ }^{\circ} \mathbf{C}\right)\end{array}$ & $\begin{array}{l}\text { Relative } \\
\text { humidity } \\
(\%)\end{array}$ \\
\hline October 2009 & 170 & 2.55 & 17.4 & 84.2 \\
November 2009 & 180 & 3.06 & 11.7 & 78.8 \\
December 2009 & 170 & 3.06 & 10.7 & 71.0 \\
January 2010 & 180 & 3.57 & 8.9 & 72.4 \\
February 2010 & 190 & 3.57 & 9.8 & 73.6 \\
March 2010 & 190 & 3.06 & 8.0 & 81.8 \\
April 2010 & 190 & 3.06 & 11.6 & 82.8 \\
May 2010 & 160 & 2.55 & 17.1 & 76.6 \\
June 2010 & 200 & 3.06 & 22.0 & 80.7 \\
July 2010 & 220 & 3.06 & 24.9 & 80.5 \\
August 2010 & 190 & 2.55 & 26.1 & 75.9 \\
September 2010 & 180 & 2.55 & 21.3 & 80.4 \\
\hline
\end{tabular}




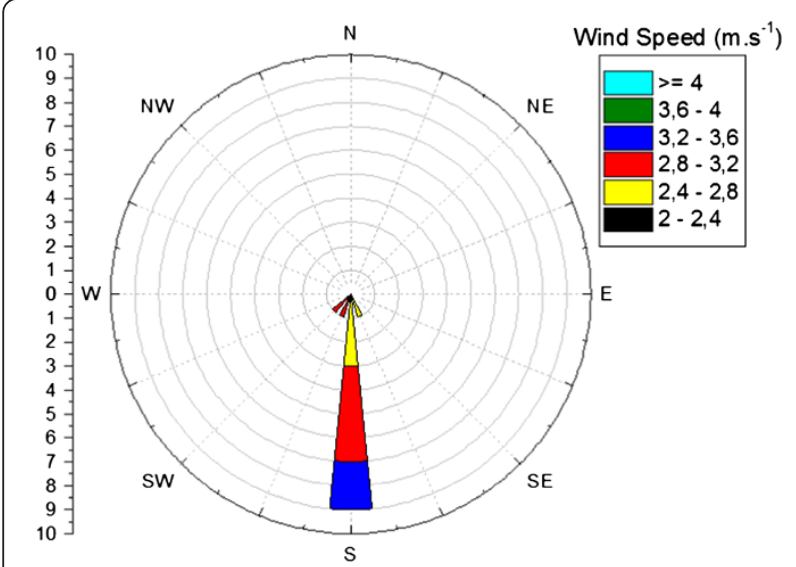

Figure 11 Values of daily average wind rose between of October 2009 with September 2010 in Çarşamba air port meteorology stations.

Carşamba Airport Meteorology Station. Figure 11 shows that air temperature is the highest correlation of $\mathrm{NO}_{2}$. The other parameters (wind speed, wind direction, and relative humidity) is a bad correlation of $\mathrm{NO}_{2}$ and $\mathrm{SO}_{2}$, which plays an important role in the distance from the meteorology station. Therefore, the results of correlation of wind speed, wind direction and relative humidity correlation had not been given in here.

\section{Conclusions}

The conclusions of this study are listed below;

1. The uninterrupted measurement station values and passive sampler readings are compared at the measurement station of the Ministry of Forestry and Water Works. A correlation of $69.24 \%$ is determined during the comparisons. When the value is corrected according to this correlation, the annual nitrogen dioxide average is calculated as $42.36 \mu \mathrm{g} / \mathrm{m}^{3}$. This value for $\mathrm{NO}_{2}$ was below the national air quality standard. But, was above the air quality standard of the European Union. However, as mentioned on the literature, meteorological parameters have significant impact on the correlation and it was not possible to make meteorological measurements at the measurement location during this study.

2. When the digital map regarding the nitrogen dioxide measurements are reviewed, it is observed that the highest level of pollution is at measurement station of Station No.3 and expands around from that location. Besides, the nitrogen dioxide values of the measurement point Number 5 at Yesilyurt Port Administration vary between 26 to $29 \mu \mathrm{g} / \mathrm{m}^{3}$.

3. It is observed that the nitrogen dioxide is intensified at locations 1, 2, 5 and 10 on the west side, starting from measurement station number 3 and expanded towards the Black Sea from location 5 or towards the inner regions of Tekkekoy from location 3.

4. When the passive samplers are compared with uninterrupted measurement results at the measurement location number 3 , in terms of sulfur dioxide, a correlation could not be established. Since the results obtained from both passive samplers and uninterrupted measurements are significantly low, we should consider the possibility of errors arising from factors having an impact on sulfur dioxide measurements and devices used. The reason for this, the sulfur dioxide concentration effected not only passive sampler measurements but also meteorological parameters.

5. It is observed that the sulfur dioxide distribution heads from south to north-west, towards the Black Sea from measurement station number 5 .

\section{Competing interests}

The author declares that he has no competing interests.

\section{Acknowledgements}

This work was financed by a scholarship of the Ondokuz Mayıs University for support of Scientific Research (Project No. PYO.MUH.1901.09.00). The author thank to Assistant Professor Aziz Şişman, Assistant Professor Nevzat Beyazıt, and Serkan Cengel for preparing of digital mapping. The author thankfully acknowledge KOSGEB, SAMGAZ, ETI Copper Inc., Blacksea Agricultural Research Institute, Milangaz, Ulusoy Maritime High School, Tekkeköy Municipality, and Yeşilyurt Company.

Received: 17 January 2013 Accepted: 27 July 2014

Published: 6 August 2014

\section{References}

1. Akdemir A: An Investigation of the Relationshios with Meteorological Parameters and Monitoring of Air Quality Parameters in Organized Industrial Region of Samsun, PhD Thesis. Ondokuz Mayis University Environmental Engineering Department; 2007.

2. Official Gazette: Air Quality Assessment and Management Legislation, No.26898. Ankara Turkey: 2008. http://www.csb.gov.tr/turkce/index.php? Sayfa=mevzuat.

3. EU (European Union): Directive 2008/50/EC of the European Parliament and of the Council of 21 May 2008 on ambient air quality and cleaner air for Europe. Official J L 2008, 152:1-44. online at [http://eur-lex.europa. eu/legal-content/EN/TXT/?uri=celex:32008L0050]

4. $\quad W H O$ (World Health Organization): Air Quality Guidelines Global Updates 2005. online at [www.euro.who.int/__data/assets/pdf_file/0005/78638/E90038.pdf]

5. NAAQS (National Ambient Air Quality Standards). 2010. online at [http:// www.epa.gov/air/criteria.html]

6. Palmes ED, Gunnison AF, Mattio JD, Tomczyk C: Personal sampler for nitrogen dioxide. Am Ind Hyg Assoc J 1976, 37:570-577.

7. Cape JN: Use of passive diffusion tubes for measuring concentration of nitrogen dioxide in air. Crit Rev Anal Chem 2009, 29:289-310.

8. Seethapathy S, Gorecki T, Li X: Passive sampling in environmental analysis. J Chromatogr A 2008, 1184:234-253.

9. Afif C, Dutot AL, Jambert C, Abbound M, Gerard JA, Farah W, Perros PE, Rizk T: Statistical approach for te characterization of $\mathrm{NO}_{2}$ concentrations in Beirut. Air Qual Atmos Health 2009, 2(2):57-67.

10. Ferm M, Svanberg PA: Cost-efficient techniques for urban and background measurements of $\mathrm{SO}_{2}$ and $\mathrm{NO}_{2}$. Atmos Environ 1998, 32:1377-1381.

11. Caballero S, Esclapez R, Galindo N, Mantilla E, Crespo J: Use of passive sampling network for the determination of urban $\mathrm{NO}_{2}$ Spatitemporal variations. Atmos Environ 2012. doi:10.1016/j.atmosenv.2012.08.071.

12. Ukpebor EE, Ahonkhal SI, Heydtman H: NO2 measurement with passive sampler:assessment of the sensitivity of two types of palmes diffusion tubes for NO2. Intern, J Environ, Studies 2004, 61(1):67-71. 
13. Taşdemir Y: Winter season $\mathrm{SO}_{2}$ measurement in Bursa and comparison with rural and urban area values. Turk J Environ Sci 2001, 25:279-287.

14. Banerjee T, Singh SB, Srivastava RK: Development and performance evaluation of statistical models correlating air pollutants and meteorological variables at Pantnagar, India. Atmos Res 2011, 99:505-517.

15. Lozano A, Usero J, Vanderlinden E, Raez J, Contreras J, Navarrete B, Bakouri HE: Optimization of the design of air quality monitoring networks and its application to NO2 and O3 in Jaen Spain. Microchem J 2010, 96:406-411. doi:10.1016/j.microc.2010.07.002.

doi:10.1186/s40201-014-0111-9

Cite this article as: Akdemir: The creation of pollution mapping and measurement of ambient concentration of sulfur dioxide and nitrogen dioxide with passive sampler. Journal of Environmental Health Science \& Engineering 2014 12:111.

\section{Submit your next manuscript to BioMed Central and take full advantage of:}

- Convenient online submission

- Thorough peer review

- No space constraints or color figure charges

- Immediate publication on acceptance

- Inclusion in PubMed, CAS, Scopus and Google Scholar

- Research which is freely available for redistribution 